\title{
LSE
}

LSE ‘Europe in Question' Discussion Paper Series

\section{The New Intergovernmentalism and the Euro Crisis: A Painful Case?}

\author{
Dermot Hodson
}

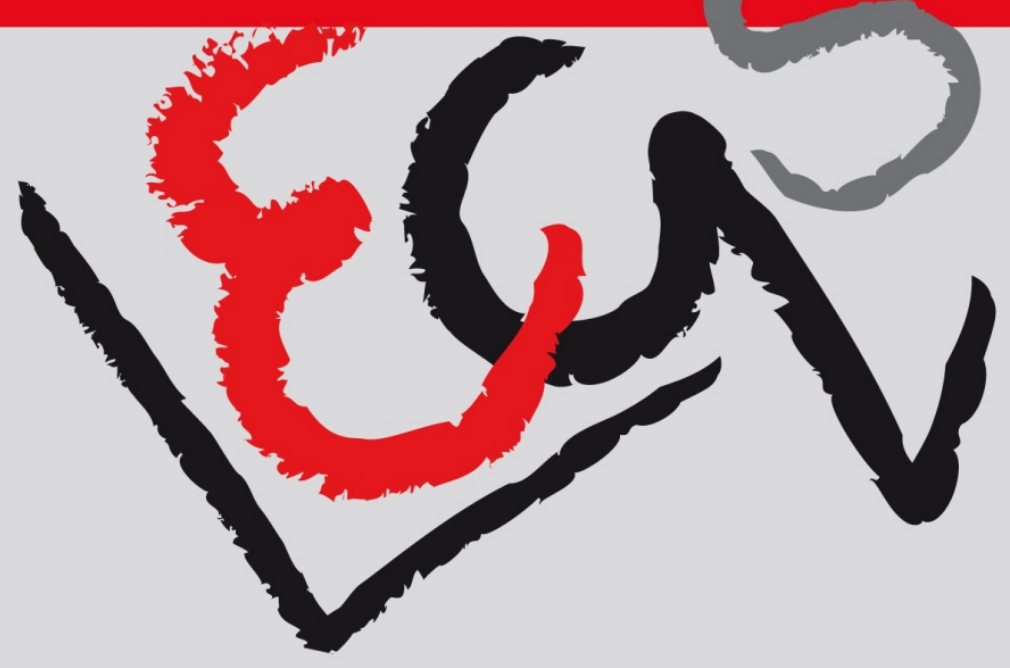




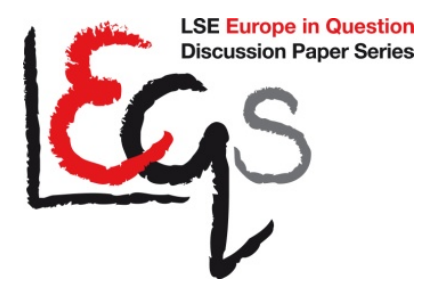

Editorial Board

Dr Bob Hancké

Dr Jonathan White

Dr Sonja Avlijas

Dr Miriam Sorace

Mr Sean Deel

All views expressed in this paper are those of the author and do not necessarily represent the views of the editors or the LSE.

(C) Dermot Hodson

Eqs 


\title{
The New Intergovernmentalism and the Euro Crisis: A Painful Case?
}

\author{
Dermot Hodson *
}

\begin{abstract}
The new intergovernmentalism seeks to understand the changing dynamics of contemporary European integration. It emphasises, inter alia, member states' preference for deliberative modes of decision-making and their reluctance to delegate new powers to traditional supranational institutions. The euro crisis is sometimes seen as a difficult case for the new intergovernmentalism because of the perceived importance of hard bargaining over crisis measures during this episode and the new roles entrusted to the European Commission and the European Central Bank under crisis reforms. Such criticisms, this paper argues, overlook: the importance of high-level consensus-seeking and deliberation in saving the single currency; the disparate forms of delegation deployed to preserve member state influence over Economic and Monetary Union; and the extent to which the euro crisis has amplified the European Union's political disequilibrium. Far from running counter to the new intergovernmentalism, it concludes, the euro crisis exemplifies the turbulent dynamics of the post-Maastricht period.
\end{abstract}

Keywords: European integration, euro crisis, integration theory, new intergovernmentalism

\footnotetext{
* Birkbeck College, University of London

Email: d.hodson@bbk.ac.uk
} 


\section{Table of Contents}

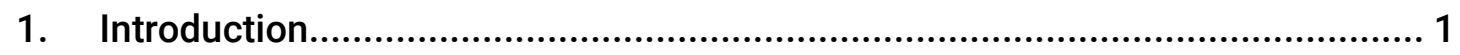

2. Problems of Preference Formation ............................................................ 4

3. A Crisis of Consensus-Seeking and Deliberation......................................... 9

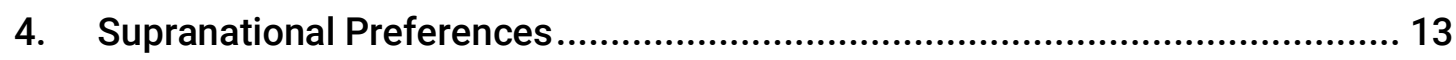

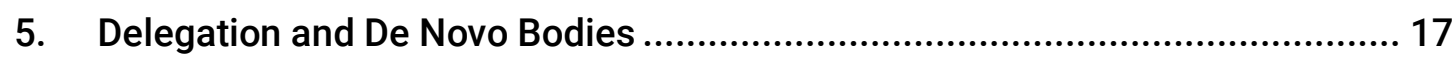

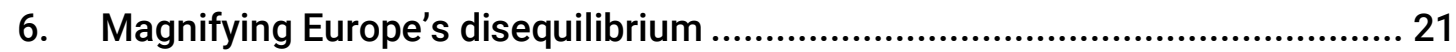

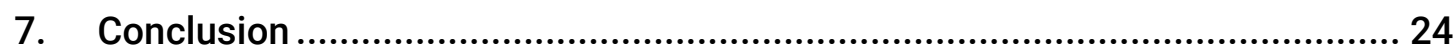

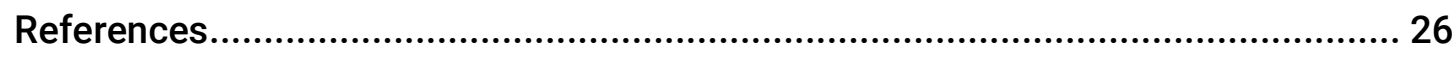

\section{Acknowledgments}

An earlier version of this paper was presented at the Institute for European Studies, IEE, at the Université Libre de Bruxelles in March 2019. Thanks to the organisers, Nathalie Brack and Seda Gurkan, my discussant, Amadine Crespy, workshop participants, and Uwe Puetter for helpful comments. The usual disclaimer applies. 


\section{The New Intergovernmentalism and the Euro Crisis: A Painful Case?}

\section{Introduction}

European integration theory is forged in crises, and individual theories can be the sum of efforts to theorise specific crises. For that reason, new periods of economic and political turmoil for the European Union (EU) pose particular challenges for existing theoretical approaches, especially if they disrupt what scholars understand to be prevailing political dynamics. Crises thus bring intellectual energy, although this energy can be misplaced if critics or proponents of particular approaches are too quick to abandon or qualify prior theoretical claims. Ernst Haas's decision to declare neo-functionalism obsolescent if not obsolete at a difficult time for the European Communities is the most striking example (Haas 1976), albeit one that he (Haas 2004) and other scholars working in this theoretical tradition rectified (Niemann and Ioannou, 2015; Schmitter 2005; Schmitter and Lefkofridi 2016). Neo-functionalism remains important for thinking about contemporary Europe, as do classical and liberal strains of intergovernmentalism (Hoffmann 2005; Moravcsik 1998, 2018). Of course, no theoretical approach(es) can claim a monopoly on understanding Europe. Nor should theoretical innovation be discouraged, especially when the EU, by virtue of its longevity, cuts across distinct periods for Europe and, indeed, the international system. 
The new intergovernmentalism treats the signature of the Maastricht Treaty in 1992 as a turning point for European integration (Puetter 2014; Bickerton, Hodson and Puetter 2015a, b; Fabbrini and Puetter 2016). Hitherto, when member states extended the scope of Community decision-making they did so by delegating new powers to the European Commission and Court of Justice. Thereafter, the new intergovernmentalism contends, integration intensified without, for the most part, delegating new powers to these traditional supranational institutions along conventional lines. Traditional theories of integration, while they have much to offer, struggle to explain this paradoxical character of post-Maastricht integration. In spite of their differences, neo-functionalism and liberal intergovernmentalism equate integration with the empowerment of traditional supranational institutions (Haas 1964; Moravcsik 1999). As a consequence, they often downplay the significance of integration since the 1990s, a view that rests uneasily with the EU's dynamism during this period. The new intergovermentalism explains this integration paradox as a choice by national governments and EU institutions intent on pursuing closer cooperation but mindful of the problems of legitimacy and trust facing EU and national elites. Such choices also reflect the blurred lines between high and low politics such that even the most prosaic areas of policy-making can be significant for national sovereignty.

Institutional choice in the post-Maastricht period is not simply an attempt to reap the benefits of cooperation, the new intergovernmentalism argues. Commercial interests are balanced by normative concerns. Preference formation is problematic for this reason, being underpinned not only by concerns over the EU's democratic deficit but a deeper crisis of representation facing European polities. Deliberation and consensus-seeking in bodies such as the Eurogroup and European Council try to square this circle by allowing national governments to extend cooperation without being seen to cede further sovereignty to the Commission and the Court of Justice. Delegation to de novo bodies responds to these tensions in a different way by allowing national governments to build shared institutions over which they maintain 
a high degree of intergovernmental control and without revising EU treaties. The traditional supranational institutions, being driven by aims other than the pursuit of ever-closer union, are complicit in this institutional dynamic. This contrasts with neo-functionalism and liberal intergovernmentalism, which see the Commission and Court of Justice as seeking to 'upgrade the common interest' and so win new powers for themselves, however much these theories disagree over the ability of such actors to achieve this objective (Haas 1964; Burli and Mattli 1993; Moravcsik 1999).

As with all attempts at theorising European integration, the new intergovernmentalism faces criticisms (see Bulmer 2015 and Schimmelfennig 2015a). A recurring charge is that this approach cannot account for European integration during the euro crisis, which began in late 2009 after Greece, and later other member states, found themselves unable to finance their public debt following the global financial crisis. ${ }^{1}$ Nugent and Rhinard (2016) argue that the Commission's increased importance as a fiscal and financial manager following the euro crisis rests uneasily with the new intergovernmentalism, as does the fact that the Commission's authority has, if anything, been strengthened by the creation of de novo bodies (Nugent and Rhinard 2016: 1209). Becker, Bauer, Connolly and Kassim (2016) reach a similar conclusion. The Commission, they argue, acted as a powerful, if more focused, engine of integration during the euro crisis, which broadened and deepened its powers over EU economic surveillance. Schimmelfennig (2015a), meanwhile, sees member states' willingness to delegate important new powers over banking supervision to the European Central Bank (ECB) as being at odds with new intergovernmentalism's claims about member states' aversion to supranational decision-making. Schmidt (2018) criticises new intergovernmentalism for failing to

\footnotetext{
${ }^{1}$ Scholars agree on the start date for the euro crisis but not on its end date. Jones (2014) treats 2012 as a terminal point, reflecting the ECB's decision to engage in large-scale bond purchases, but this was three years before a standoff between Greece's government and its international creditors triggered a period of intense turmoil for the single currency. Greece exited its financial assistance programme in August 2018, the last eurozone member to do so, although tensions between Italy and the European Commission later that year raised concerns that the euro crisis might not be over.
} 
make explicit the power dynamics in euro crisis deliberation and decision-making. Germany did not impose solutions on Greece and other member states in the crisis, she suggests, but the German government entered deliberations with 'outsize power', which it was not afraid to use (Schmidt 2018: 6).

These criticisms provide an opportunity to clarify and refine the new intergovernmentalism. Far from being a difficult case, this paper argues, the euro crisis chimes with new intergovernmentalism's key claims. First, the crisis illustrates the problems of preference formation in the post-Maastricht period, with governments' responses to the single currency's problems informed not only by commercial interests but also by Europe's legitimacy crisis. Second, member states' institutional choices during the euro crisis exemplify the importance of deliberation and consensus-seeking through bodies such as the European Council and Euro Summit and their preference for empowering de novo bodies. European Banking Union, it notes, is far from being a straightforward example of delegation to supranational institutions. Third, the crisis confirms the Commission's ambivalence about ever closer union, most noticeably under the presidency of José Manuel Barroso but also, in a more complex way, under that of Jean-Claude Juncker. Finally, member states may have saved the euro but they did so by aggravating rather than alleviating the political disequilibrium facing the EU.

\section{Problems of Preference Formation}

The new intergovernmentalism takes as its starting point the fact that political contestation around European integration emerged as an element in the constitution of national preferences in the post-Maastricht period. This contrasts with liberal intergovernmentalism, which rests on a 'societal' model of preference formation that places particular emphasis on commercial interests, especially the economic interests of powerful producer groups and, secondarily, the macroeconomic preferences of governing coalitions (Moravcsik 1998: 3). Commercial interests matter for new intergovernmentalism but they interact in often unpredictable and indeterminate 
ways with normative concerns, including, in particular, a distrust of national elites and a widespread disenchantment with the process of political representation. Concerns about legitimacy, felt by national governments as well as by EU institutions, have thus become part of preference formation.

Schimmelfennig (2015b) sees the euro crisis as a fairly straightforward example of preference formation à la liberal intergovernmentalism. Moravcsik (1993: 493-4) views macroeconomic policy as being subject to diffuse societal preferences because this domain of decision-making is largely concerned with the provision of public goods. Schimmelfennig sees the euro crisis as a special case because financial turmoil and policy responses to it had direct implications for financial institutions, with the result that producer groups had less diffuse preferences than usual in this policy domain (Schimmelfennig 2015b: 180). Member state governments also had a shared interest in saving the euro, Schimmelfennig (2015b: 181) argues, because the dissolution of the eurozone would have been costly for all concerned. Where member states disagreed, he suggests, was over the question of whether the costs of crisis management should be borne collectively or nationally, with such differences rooted once again in socio-economic considerations: northern member states with strong fiscal positions favoured the second of these options while southern member states facing insolvency or the risk thereof favoured the first. This view of the euro crisis broadly chimes with Moravcsik (2012), who sees member states as defending the euro, if only because the short-term costs of dissolving the single currency would be so great.

This account of preference formation in the euro crisis is compelling but it arguably overstates the extent to which societal preferences were united behind saving the single currency through deeper integration while underplaying the impact of public opinion and party politics on member state governments. Northern European banks, as both Moravcsik (2012) and Schimmelfennig (2015b) observe, were heavily exposed at the start of the crisis to sovereign debt issued by the eurozone's so-called vulnerable periphery, helping to explain the former's desire to see governments 
provide financial assistance to the former. Banks soon reduced their exposure, however, and with this modified their view on the euro crisis. That the combined exposure of France and Germany to the eurozone periphery fell from $\$ 1.9$ trillion in 2008 to $\$ 800$ billion in 2012 (Minenna 2018) helps explain why economic interest groups became more relaxed about the idea that the eurozone, in its existing form, might not survive. Five years after the Institute of International Finance campaigned actively for financial assistance to Greece (Kalaitzake 2017), this powerful industry group was sanguine, in 2015, about the prospects for Grexit (Atkins and Slater 2015). Less than half of business leaders in the eurozone surveyed in 2015 thought that Grexit would be harmful to the euro (Grant Thornton 2015: 8).

Producer groups ultimately supported efforts to save the single currency during the euro crisis but they were not uniformly in favour of more Europe. A survey of eurozone business leaders in 2013 showed that 66\% favoured deeper economic integration compared to $40 \%$ for deeper political integration (Grant Thornton 2013). It also revealed significantly higher support for political integration among German business leaders (61\%) compared to their French counterparts (35\%). In Germany, large commercial banks favoured a greater role for the EU in financial supervision but the country's savings and cooperative banks pushed back (Hennessy 2014). Elsewhere in the eurozone, interest groups were largely disinterested in reforms over the European Stability Mechanism (Bojovic, Munta and Puetter 2018).

If the interests of producer groups over the euro crisis were more diffuse than they looked, so too were the macroeconomic preferences of governing coalitions. For highly-indebted countries, euro exit would almost certainly have been turbulent; however, it would have brought degrees of policy freedom in the short term that member states lacked by staying in the eurozone, including currency devaluation, an escape from a debt-deflation trap and a more straightforward route to debt restructuring (Papanikos 2015). For surplus countries, the dissolution of the eurozone provided an opportunity to rebuild the European monetary system around a more homogenous and macro-economically like-minded group of member states, as 
occurred in the 1970s after the Snake in the Tunnel was replaced by a deutschmark zone. It also offered an escape from the unconventional and potentially inflationary crisis policies of the ECB. Members of the governing coalition in Greece and Germany were drawn in different ways to these arguments. Yanis Varoufakis consistently denies that he supported a return to the drachma during his brief tenure as Greek finance minister but he reportedly commissioned work on a parallel currency and suggested that some cabinet colleagues favoured Grexit (Smith 2015). Wolfgang Schäuble, Germany's finance minister and a longstanding advocate of core Europe, argued strongly that Greece be offered a 'timeout' from the eurozone and, in July 2015, convinced finance ministers to put this option to the European Council (Karnitschnig 2015). That the heads of state of government stood by the single currency was not just because its dissolution would have been economically disruptive but also because of their political commitment to European economic cooperation, argues Barry Eichengreen (2010).

The most clear-cut constraint on member state governments during the euro crisis came not from pressure groups or governing coalitions but from public opinion and party politics. Public support of the ECB plummeted during the euro crisis (Roth, Jonung and Nowak-Lehmann 2016), as it did more generally in political institutions (Foster and Frieden 2017). In April 2007, 58\% of EU citizens said that they tended to trust the EU (source: Eurobarometer Interactive). By November 2013, this figure had fallen to $31 \%$. The percentage of respondents expressing trust in national government fell from $43 \%$ to $23 \%$ over the same period. 'Europeans should trust in the essentially democratic nature of the EU, which will encourage them to distribute the costs of convergence more fairly within and among countries', argued Moravcsik (2012: 55). Many Europeans, it would seem, were otherwise inclined.

Governing parties that mismanage the economy stand a higher chance of losing office but the electoral backlash that followed the euro crisis went beyond this effect. Voters not only punished incumbents, Hobolt and Tilley (2016) observe. All mainstream parties saw their combined vote share decline from $86 \%$ in 2004 to $72 \%$ 
in 2015. The challenger parties that benefitted from this opportunity were not all Eurosceptic, Greece's Syriza being a case in point. However, a core of anti-euro parties rode this political wave, including the True Finns, the Party for Freedom, Rassemblement national, Alternative für Deutschland (AfD), the League and the Five Star Movement. Such challengers shared not only an aversion to deeper eurozone integration but also a desire for a referendum on either eurozone or EU membership. Although mainstream parties resisted such pledges they became increasingly cautious about eurozone reforms that might trigger significant EU treaty amendments and so add to pressure for a public vote. Treaty change was taboo under the Hollande administration, admitted its former economics minister Emmanuel Macron (Gotev 2017).

Faced with these legitimation challenges, member state governments sought to save the euro while avoiding the delegation of significant new policy-making powers to EU institutions where possible. Governments, as the democratically elected representatives of sovereign states, play a powerful role in legitimating EU decisionmaking in liberal intergovernmentalism. New intergovernmentalism instead sees governments as acutely aware of their own problems of representation and it was such concerns, which help to explain preference formation in the euro crisis. Reforms in response to this crisis were more consistent with the second of these views; existing treaty provisions were used and stretched where possible, with member states seeking more ambitious changes through international law treaties from which EU institutions were kept at arm's length and which could enter into force without the approval of all member states (Hodson and Maher 2018: Chapter 8). The revision of Article 136 of the Treaty on the Functioning of the European Union was an exception undertaken only when a challenge to the European Stability Mechanism in national higher courts seemed inevitable and only then under the Treaty's Simplified Revision Procedure, thus minimising the scope for a public vote in member states such as Ireland. 


\section{A Crisis of Consensus-Seeking and Deliberation}

A defining feature of the post-Maastricht period, the new intergovernmentalism contends, is how consensus-seeking and deliberation have become guiding norms in day-to-day decision-making. Bickerton, Hodson and Puetter (2015a) see consensus as an end in itself driven by member states' determination to reach agreement on shared policy challenges. Threats of vetoes or exit are anathema to this working method, as is settling for prolonged stalemate. New intergovernmentalism understands deliberation, meanwhile, as member states' attempt to work through national differences on contentious matters and at the very highest levels of EU policy-making. Liberal intergovernmentalism does not overlook such norms but it has different understandings of - and expectations about - them. For Moravcsik (2018: 1657) member states frequently resort to consensus to oil the wheels of intergovernmental bargaining, for example, by offering opt-outs and concessions to recalcitrant states. He sees deliberation as a more infrequent attempt to transform identities and preferences through argumentation, which lends itself to low-stakes or high-consensus issues.

The rise of the Eurogroup and European Council in the post-Maastricht period reflects these new intergovernmental dynamics. At the time of the single currency's launch, eurozone members sought to coordinate economic policies and yet remained reluctant to cede further sovereignty in this sphere. The Eurogroup squared this circle by providing a forum in which eurozone finance ministers could engage in informal dialogue and deliberation outside the strictures of the ECOFIN Council. A broad convergence in economic ideas between finance ministers made such cooperation possible, if far from plain sailing. Similar dynamics can be seen in the hands-on role assumed by the European Council in the Lisbon Strategy's economic reform agenda and in formulating collective responses to the global financial crisis. In both cases, heads of state or government went well beyond the European Council's traditional role in providing overall direction to the EU to puzzle over complex policy problems. 
The euro crisis was a high-stakes affair that saw no shortage of hard bargaining or power politics. Germany has rarely appeared more dominant in EU decision-making (Bulmer 2014) and even smaller member states fought hard to protect their interests, as in Finland's demand for collateral in negotiations over financial assistance programmes (Moulds 2012). The Euro Summit's treatment of Greece in the summer of 2015, moreover, stretched the idea of consensus-seeking to its limits. Having tried but failed to seek more favourable terms with its creditors in spite of domestic backing in an anti-austerity referendum, the government of Alexis Tspiras reluctantly accepted even harsher conditions in return for a third financial assistance programme. While the Greek Prime Minister and the German Chancellor Angela Merkel thrashed out the terms of this deal, the hashtag \#ThisIsACoup trended on Twitter.

At the same time, it is hard to imagine how the euro would have survived had hard bargaining alone been employed. Heads of state or government remained steadfast in their commitment to the single currency not because the breakup of the eurozone would have been costly but in spite of the short-term incentives that some faced to return to national currencies. Although she faced a degree of domestic pressure for Grexit, including from her own finance minister, Merkel sought to avoid this scenario at all costs. 'If the euro collapses then Europe and the idea of European union will fail', she told an audience in Aachen in May 2010 (Irish Times 2010). Even Tspiras, for all his radicalism, resisted a return to the drachma. His position was not one of Euroscepticism but anti-globalisation, which explains his concerted efforts to remove the IMF from the Troika even though the Fund cut a less hawkish figure than the Commission at times. In the most comprehensive study of euro crisis negotiation to date, Lundgren, Bailer and Dellmuth (2019) find that power resources cannot explain negotiating outcomes. Commitment to economic and financial integration and the dynamics of compromise and reciprocity offer more powerful explanations, they find, marking the EU out from other international organisations. 
Threats of vetoes or exit were exceptional during the euro crisis and ran contrary to the EU's approach to the crisis, as both George Papandreou and David Cameron discovered. The former broke from the EU's consensus-seeking norms by announcing a referendum on the terms of financial assistance from the EU and IMF. Within a week, Papandreou had called off this referendum amid fierce opposition at home and from EU partners. Within a fortnight, he had resigned as Prime Minister. Having refused to support plans for an EU treaty amendment on euro crisis reforms, the British Prime Minister Cameron found himself isolated after all other member states except the Czech Republic pressed ahead with plans for an international law treaty, the Fiscal Compact. Alexis Tspiras's anti-austerity referendum in June 2015 was a largely symbolic affair. After Greek voters resoundingly rejected the conditions sought by the EU and IMF in an earlier, abandoned round of negotiations, the Greek Prime Minister fired his finance minister and prepared to strike a deal to keep his country in the eurozone.

The euro crisis was not just a political one for the EU but an ideational one, which exposed the limits of the prevailing policy paradigm and reignited divisions between Keynesian and ordoliberal traditions. Whereas France, a traditional torchbearer for Keynesianism, was an early advocate for fiscal stimulus and financial assistance, Germany, in true ordoliberal fashion, preached balanced budgets and the dangers of moral hazard (Bohn and De Jong 2011). And yet, the deliberative modes employed by member states proved sufficient to work through such differences. Had the Merkel administration been as entrenched in its ordo-liberal thinking as some suggested, then it would not have accepted the degree of flexibility permitted in the design and implementation of the six pack and Fiscal Compact. Nor would it have tolerated the ECB's bond buying programme, financed the lion's share of loans to Cyprus, Greece, Ireland, Portugal and Spain or accepted the decision in June 2018 to provide debt relief to Greece. Van Esch's (2014) cognitive mapping of key speeches by eurozone leaders during the crisis contrasts the ideational flexibility shown by the German Chancellor with the more rigidly ordoliberal views of Bundesbank president 
Axel Weber. Merkel's refusal to back Weber for the post of ECB president and the latter's resignation from the Bundesbank before his term of office expired come as little surprise in the light of such findings.

Member states' commitment to consensus-seeking and deliberation during the euro crisis found voice in the Eurogroup and when this forum struggled to find a way forward, the Euro Summit. The latter embodied a new intergovernmental logic by bringing together eurozone heads of state or government for closed-doors discussions on the most vexing aspects of crisis management (Puetter 2016). Its impact was almost instantaneous. At their first meeting in February 2010, eurozone leaders bridged national differences over IMF involvement in the unfolding sovereign debt crisis and agreed to dispatch the Troika to Athens. An agreement, in principle, on financial support for Greece came a month later. Decisive too was the Euro Summit's all-night talks in July 2015 on a third financial assistance package for Greece. When talks threatened to break down before dawn, European Council President Donald Tusk reportedly told Merkel and Tsipras: 'I'm sorry, there is no way you are leaving this room' (Chassany et al., 2015), encapsulating in one phrase the deliberative dynamics of new intergovernmentalism.

EU heads of state or government played a central role too in the reform agenda initiated by the euro crisis. The creation of a European Council working group on output gaps illustrated the blurred dividing line between high and low politics postMaastricht, with technical discussions over this macroeconomic indicator deemed sufficiently political to include representatives of the heads of state or government. More generally, the European Council and Euro Summit played a detailed and prominent role in reform debates. In March 2010, Herman Van Rompuy, the first full-time President of the European Council, was appointed head of a taskforce to explore options for reforming the EU's fiscal rules and crisis resolution framework. In June 2012, Van Rompuy was invited to develop proposals for the achievement of a 'genuine EMU' in close collaboration with the presidents of the European Commission, ECB and Eurogroup. That the President of the European Commission 
was not asked to lead these initiatives showed how the dynamics of European integration had shifted since the days of the Delors Report. Jean-Claude Juncker would regained some of this initiative when he was entrusted to prepare a follow-up report (see below) but the most important and contentious aspects of eurozone reform from 2010 onwards were settled by the heads of state or government.

\section{Supranational Preferences}

The euro crisis provides an important test of whether the Commission is hardwired for ever closer union, a central, if contested, claim of the new intergovernmentalism. The Commission, it should be stressed, is not a languid or declining institution from this theoretical vantage point. It is rather an institution that invests its energies into projects other than its own empowerment. The new intergovernmentalism thus questions the assumption underpinning disparate theories of European integration and governance that the Commission is, for reasons of self-interest or ideology, a competence maximising institution (see, for example, Pollack 2003; Cooley and Spruyt 2009).

There are two principal reasons for the Commission's ambivalence about ever-closer union post-Maastricht (Hodson 2013). The first sees this institution as a strategic actor, which is reluctant to put forward proposals that stand little chance of success. The prospects for supranational entrepreneurship in early periods should not be exaggerated but member states' preference for intergovernmental modes of decisionmaking and declining popular support for integration since the 1990s explains why the Commission has been so cautious about ever-closer union since Maastricht. The second sees the Commission as being more than just a competence maximiser. The trend towards choosing the President from the ranks of current or recent members of the European Council may explain the Commission's preference for intergovernmentalism, as might ideological divergence at the level of Commission services (see Kassim et al 2013). The Commission also emerges as a more partisan body during this period thanks to the introduction of qualified majority voting for 
nominating the Commission President and the end to the practice whereby large member states nominated one Commissioner from each of the two main political parties (Hix 2008).

José Manuel Barroso's cautious response to the euro crisis, and the global financial crisis before it, exemplifies this new intergovernmental view of the Commission. When Europe's banking system faced systemic risks in the second half of 2008, French President Nicolas Sarkozy saw an opportunity to regulate Anglo-Saxon capitalism. The Commission President belatedly spoke out against 'futile attempts to stem financial globalisation' (European Commission 2008) 'grand initiatives that have no chance of being followed through' (Barroso 2008). When the euro crisis struck, Barroso supported the reform of the stability and growth pact but only after member states had agreed to re-open the EU's fiscal rules. The Commission President can claim to have set the agenda over initial attempts to strengthen financial supervision, but he followed member states' lead on European Banking Union and the creation of crisis resolution mechanisms.

Having assigned key economic portfolios to free marketeers during his first term, Barroso saw his College of Commissioners pulled in a more interventionist direction in this second term. While Internal Market Commissioner Charlie McCreevy had showed little appetite for stringent financial regulation even after the global financial crisis hit, his successor, Michel Barnier, sponsored a string of reform proposals. Having tried but failed to assign Barnier a different brief, the Commission President had little choice but to acquiesce. As his term of office drew to a close, Barroso grew bolder, mindful perhaps of his legacy. In his State of the Union Speech for 2012, the Commission President expressed his support for economic, financial and political union. This was not a damascene conversion, however. He used the terms loosely, with economic union, for example, evoked in relation to reforms already on the agenda rather than any radical transfer of decision-making to the Commission. 
Jean-Claude Junker is a more complicated case for the new intergovernmentalism (see Sanjurjo Hanck 2018). Through the Five Presidents Report, the Commission's White Paper on the Future of Europe and the follow-up reflection paper on deepening EMU, Juncker showed dynamism that his predecessor lacked. Nevertheless, the reform proposals put forward by the Luxembourg Prime Minister remained circumspect about upgrading the common interest. While the Five Presidents' calls for financial, fiscal and political union had a centralising ring, these proposals avoided a significant transfer of new policy-making powers to the Commission. Indeed, many of its most ambitious ideas concerned the creation or reform of de novo bodies such as a common backstop for the Single Resolution Fund, a European Fiscal Board and a eurozone treasury. ${ }^{2}$ The Report's unease with such 'intergovernmental solutions' is reflected in its calls for the Single Resolution Fund and the European Stability Market to be eventually integrated 'into the framework of EU law' but this ambition was a long-range one at best (Juncker 2015). The Five Presidents in general - as well as Juncker, in particular - had good reasons not to trigger major treaty amendments at this time, not least because of UK Prime Minister David Cameron's determination to link eurozone reforms to a British referendum on continued membership.

The Juncker Commission's hesitancy about ever-closer union was clearer still from its White Paper on the Future of Europe, which explored five alternative scenarios for how the EU might evolve by 2025 (European Commission 2017a). Only two of these involved deeper integration among some or all member states, the others considered the status quo or a narrowing of the EU's activities. Far from an act of entrepreneurship by Juncker, the White Paper was, as one commentator put it, 'intended to throw the ball back to member states to decide on the path of integration, after several backlashes against his initiatives to move integration forward' (Morrilas 2017). That Jean-Claude Juncker presented his own 'sixth

\footnotetext{
${ }^{2}$ The report made the case for a eurozone stabilisation instrument but remained vague about how it would work or where it would be situated in the EU's institutional architecture.
} 
scenario' just six months later suggested that his administration was divided on this approach. And yet, Juncker's scenario brought little clarity to this exercise, especially in relation to EMU. Aside from proposing a euro-accession instrument to provide technical and, perhaps, financial assistance to member states seeking to join the eurozone, the Commission President provided little more than a general declaration of 'European' values and an implicit rebuke to Emmanuel Macron's plans for a multi-speed Europe (Juncker 2017: 5-6). Ultimately, the Juncker administration was at pains to let member states lead on such reform debates rather than being seen to impose its ideas from above (Russack 2017: 7). The Commission's accompanying reflection paper also avoided championing a bigger role for itself in relation to eurozone governance (European Commission 2017b). One exception concerned the report's insistence that any eurozone stabilisation mechanism be embedded within the EU's multiannual financial framework, thus ensuring Commission involvement in the governance of such a mechanism. Other proposals clipped the Commission's wings, as in the idea of putting the Commission's economic surveillance tasks under the control of a new EU finance minister, who would sit within the Commission and the Council of the EU.

The real puzzle from a new intergovernmentalist perspective is not why Juncker rekindled the pursuit of ever-closer union - he didn't for the reasons set out above but why he was more willing than Barroso to lead reform debates. One explanation is that he was given licence to do so by member states, who were content, for example, to let the Commission President rather than the European Council President Donald Tusk take charge of the Five Presidents Report. Tusk was not only less experienced; he came from a member state that showed no appetite for joining the eurozone. But member states' enthusiasm for far-reaching reforms should not be exaggerated. Their reaction to this report and the Commission's White Paper were predictably lukewarm.

It is not only the Commission that is ambivalent about ever-closer union, the new intergovernmentalism suggests, but also the Court of Justice of the EU. Through its 
post-Maastricht case law, Marie-Pierre Granger (2015: 209) suggests, the Court is 'generally deferential towards intergovernmental coordination or decision-making processes, and is much less inclined to push for supranational mechanisms at all costs'. This tendency was certainly discernable when the Court was drawn into the euro crisis. In Pringle, the Court rejected arguments by an Irish parliamentarian before the Irish Supreme Court that the ESM Treaty was unlawful, thus ensuring that the financial assistance granted by the EU to eurozone members could continue. In Gauweiler, the Court ruled that the ECB's Outright Monetary Transactions (OMT) was permissible under the EU treaties following a challenge before the Bundesverfassungsgericht. Through these rulings, the Court ensured that policy responses to the euro crisis could continue. Had it ruled otherwise, crisis management would have been greatly - perhaps prohibitively - complicated. In neither case, however, did the Court advance a supranational vision of integration. In Pringle, indeed, the Court took a pragmatic view of intergovernmental decisionmaking (Borger 2013). Member states were free to establish the ESM outside the scope of EU law, it ruled, on the understanding that the commitments undertaken by member states are compatible with EU law. ${ }^{3}$ Member states could also, it decided, entrust tasks to EU institutions outside the framework of the EU - as occurred with the ECB and the Commission in relation to the ESM - so long as such tasks did not encroach on areas in which the EU enjoys exclusive competence or alter the powers conferred on these institutions under the treaties. ${ }^{4}$

\section{Delegation and De Novo Bodies}

The new intergovernmentalism does not see the Commission as being in decline post-Maastricht (Peterson 2015). It accepts, for one thing, that this institution retains the significant policy-making powers it acquired in the pre-Maastricht period in areas such as competition and external trade policy. Furthermore, as discussed

\footnotetext{
${ }^{3}$ Pringle v Government of Ireland (2012) C-370/12, para. 109

${ }^{4}$ Pringle, para. 158
} 
above, the Commission is not necessarily seeking to extend its own powers. What constitutes a 'win' for the Commission is consequently changing over time. It may prefer to consolidate its existing competences, pursue partisan political objectives or avoid prominent roles in contentious policy areas given its own problems of legitimacy and those facing the EU. Or it may prefer the empowerment of de novo bodies to the status quo of no delegation or simply be resigned to its fate.

Bauer and Becker (2014) are right to see the Commission's new role in crisis management as significant. But the effect of these particular reforms should not be overstated. Nor should they detract from the significant powers granted to de novo bodies during this period. Both the six pack and Fiscal Compact have reinforced the Commission's role in EU economic surveillance. They increase the scope of EU fiscal surveillance, paying greater attention to expenditure and debt dynamics, and intensify monitoring of current account balances, housing prices, inflation differences and other potential drivers of macroeconomic imbalances. Financial penalties can be deployed under a wider range of circumstances and a new reverse majority rule ensures that Commission's recommendations for corrective action under various stages of the excessive deficit and macroeconomic imbalance procedures take effect unless a qualified majority of member states disagree. The Commission may have 'won' from these reforms but its victory has been modest. Its surveillance of member states' economic policy has been much more detailed and intrusive but it been less constraining on member states than some anticipated. As of 2018, no member state had faced financial penalties for breaching the excessive deficit procedure and the Commission had showed a willingness to investigate but not prosecute member states for posting excessive imbalances (Hodson 2018). Member states have been granted significant leeway to get government borrowing under control with JeanClaude Juncker, in particular, making good on his promise to use the stability and growth pact's flexibility (Juncker 2014: 34).

The Commission's involvement in the negotiation and monitoring of loans to eurozone members also brought a degree of intrusion into the affairs of a member 
state not explicitly envisaged at Maastricht. Commission officials became prominent actors and, at times, political targets in domestic politics as they visited national capitals on review missions to assess fiscal plans and reform progress. To suggest however, as Fritz Sharpf (2011) has done, that Greece and other 'programme countries' were subject to 'the dictates of Commission bureaucrats' is inaccurate. The conditions attached to loans were not imposed on member states from the Berlaymont; they emerged from a process of negotiation between governments and their creditors. The asymmetry in such bargains should not be overlooked but nor should the fact that, as Michael Breen (2012: 81) puts it, 'politicians and officials from the borrowing country have input into programme design and are ultimately responsible for implementation'. Key decisions on EU programme financing and loan disbursement were taken not by the Commission but by the Eurogroup, which in turn operated in the shadow of the Euro Summit and European Council. The IMF's involvement in these arrangements further reflected the reluctance of Germany and other member states to delegate new powers to the Commission during the euro crisis (Hodson 2015b). The two pack confirmed this reluctance to delegate along traditional lines by involving the IMF alongside the Commission in reinforced surveillance for member states at risk of fiscal or financial crises.

De novo bodies can exist inside or outside EU law but they tend to have simple, issue-specific mandates in contrast to the broad range of responsibilities entrusted to traditional Community institutions (Bickerton, Hodson and Puetter 2015a). Simple does not mean static (Scipioni 2018) since these bodies' mandates can evolve over time. Nor are these bodies merely advisory; they can exercise significant executive or legislative functions that could, in principle have been delegated to the Commission, even if the Commission is not necessarily opposed to the empowerment of such institutions. A handful of de novo bodies were created in the pre-Maastricht period, the European Investment Bank (1958) being the first, but more than 40 have been created since the 1990s. The structure of these institutions is not identical; some have 
governance structures with supranational elements, but most are essentially intergovernmental (see Hodson and Peterson 2017).

Member states were altogether more willing to delegate powers to de novo bodies during the euro crisis because they allowed member states to formulate collective responses without seeking new powers for the Commission in contentious areas (Lequesne 2016). The creation of the European Financial Stability Facility (EFSF) was a curious exhibit in this respect, this temporary crisis fund being created in May 2010 as a public limited company under Luxembourg law and accountable to member states, not as sovereigns but as shareholders. That the EFSF's functions could have been delegated to the Commission can be seen from the European Financial Stabilisation Mechanism (EFSM), a smaller fund created in May 2010 and managed by the Commission, which was soon superseded by the EFSF and ESM. ${ }^{5}$ Giving the Commission control over a crisis resolution fund, even a limited one, was simply too sensitive.

The ESM, a permanent crisis fund launched in 2012, is the most important de novo body created during the euro crisis. The intergovernmental design of the ESM reflects member states' determination to keep de novo bodies at arm's length from the EU's decision-making structures. Key decisions are taken by a Board of Governors composed of eurozone finance ministers and the Eurogroup president as its chair. The Commission is given a key role in negotiating and monitoring the conditions attached to ESM loans-alongside the ECB and IMF-but it attends meetings of the ESM Governing Council in an observer capacity only and has no say over ESM resources.

New intergovernmentalism struggles to explain the empowerment of the ECB, argues Schmidt (2018), which has significantly expanded its mandate. But this argument overlooks the fact that the ECB represents one of the most consequential

\footnotetext{
${ }^{5}$ The EFSM was briefly revived in 2015 to provide short-term loans to Greece but only as a last resort and amid considerable political controversy.
} 
examples of delegation to a de novo body in the post-Maastricht period (Hodson 2015). ${ }^{6}$ The Bank saw its responsibilities increase under European Banking Union but this was not an entirely straightforward act of delegation. For one thing, member states were determined not to confer new competences on the ECB, relying instead on a not uncontroversial reading of the Treaty's provisions on financial supervision rather than seeking a treaty amendment (Alexander 2016: 478-9). Moreover, the planning and execution of these supervisory arrangements were delegated not to the ECB Governing Council but to a new Supervisory Board sitting within the Bank. The Supervisory Board includes representatives from all national supervisory authorities as compared with four from the ECB, making it a de novo body within a de novo body. Moreover, the Single Supervisory Mechanism has direct responsibility for the supervision of only the largest and most systemically significant banks. National supervisors monitor the rest as well as participating alongside ECB officials in socalled joint supervisory teams.

The Single Resolution Mechanism - the second pillar of European Banking Union - is a more conventional de novo body. Its governance structure is no more diffuse for this. Under proposals put forward by the Commission in July 2013, the Commission would have been formally responsible for deciding whether a failing bank should be resolved. This proposal went too far for the ECOFIN Council, which decided that the question of whether to resolve a bank should rest with the ECB and national representatives but not the Commission (see Howarth and Quaglia 2014).

\section{Magnifying Europe's Disequilibrium}

New intergovernmentalism is much less sanguine about the state of the EU than some contemporary theoretical accounts of European integration. Whereas liberal intergovernmentalism thinks of the $\mathrm{EU}$ as arriving at a stable institutional equilibrium after Maastricht (Moravcsik 2005), new intergovernmentalism sees the

\footnotetext{
${ }^{6}$ See Hodson (2015a) for a deeper discussion of the ECB as a de novo body.
} 
EU as being in a persistent state of disequilibrium because of the disconnect between the pro-integration consensus among policy-makers and some sections of European society over the direction of the EU. This argument does not hearken back to some golden age in which the EU was in equilibrium; rather, it sees the EU, in Eastonian terms, as a dynamic political system that has become prone to produce dysfunctional policy outputs that undermine political support for European integration and cast doubt on the further integration of the Union (Hodson and Puetter 2018). Previous periods witnessed political discontent and crises over European integration, to be sure, but the post-Maastricht period is the first in which member states have pressed on with integrationist initiatives in spite of widespread public disquiet about - and organised opposition to - the EU. Eurosceptic parties occasionally flourished before 1992, as in the strong showing of Denmark's Progress Party in 1973, but they have only become a pervasive feature of EU politics since Maastricht (Usherwood and Startin 2013). That EU policy-makers have pressed ahead with European integration in spite of such tensions runs the risk, the new intergovernmentalism contends, that the EU's political disequilibrium will unwind in a disorderly and perhaps even a destructive manner (Hodson and Puetter 2019).

The euro crisis has amplified the EU's disequilibrium by ushering in a new period of integration in spite of the challenge to the EU's legitimacy and that of member state governments. The incremental, just-in-time nature of euro crisis reforms also fuelled the public impression that eurozone leaders were permanently behind the curve - a problem captured in Jones, Kelemen and Meunier's (2015) idea of 'failing forward' even if there was little public appetite for more ambitious integrationist initiatives.

That the integrationist steps taken in response to the euro crisis - and not just the crisis itself - weighed on the EU's legitimacy can be seen from the case of the AfD, a party created in 2013 to oppose Germany's contribution to financial assistance programmes. The German government's support for a single currency has always posed challenges for liberal intergovernmentalist accounts of EMU given the Bundesbank's track record at securing economic stability and public attachment to 
the deutschmark. AfD exploited the gap between political and public support in this member state to spectacular effect. Having campaigned to seek the dissolution of the euro, it became Germany's main opposition party in the 2017 federal elections. Angela Merkel's grand coalition was returned to power and although it continued to engage in eurozone reforms, it was a much-diminished political force.

What an unwinding of the post-Maastricht disequilibrium might look like for the eurozone can be seen from Marine Le Pen's 2017 presidential manifesto, which promised to restore monetary sovereignty to the French people before holding a referendum on the country's membership of the EU (Le Pen 2017). It can be seen too in Italian Europe minister Paola Savona's Plan B for Italy, which envisaged a disorderly exit from the eurozone without a referendum and default on the Banca d'Italia's liabilities vis-a-vis ECB under Target2 (Gros 2018). Liberal intergovernmentalists are confident that such challenger parties will moderate their views where they win power (Moravcsik 2018: 1663) but new intergovernmentalism is not so sure. Italy's League and the Five Star Movement may have backtracked on anti-euro statements before they entered government in 2018 but both parties remain critical of eurozone governance and confrontational in their dealings with EU institutions. The League's talk in June 2019 of issuing mini-BOTs (low-denomination, non-interest-bearing treasury bills) to settle government debt, furthermore, renewed doubts over Italy's long-term place in the eurozone. Comparisons between the Italian case and Syriza's political journey in Greece are problematic. Alexis Tsipras's commitment to euro membership meant that he was willing to endure painful reforms and the fracturing of his own party to win back the confidence of financial markets. It is unclear whether Italy's coalition government would be willing or able to follow suit if the country's sizeable public debt and fragile banks once again ignite concerns over Italexit. 


\section{Conclusion}

The new intergovernmentalism seeks to understand the changing dynamics of European integration in the post-Maastricht period. It makes no claims to be a grand theory of regional integration, not least as it is concerned with a specific period in the evolution of the EU. And yet, new intergovernmentalism defends integration theory's engagement with grand ontological questions that were largely set to one side by the 'governance turn' in the 1990s and 2000s and sees commonality between Europe's crisis of representation and the global trust deficit in national and international policy-makers. Nor does new intergovernmentalism claim a monopoly on understanding Europe. Indeed, it is intrinsically wary of attempts to police theoretical, methodological and disciplinary boundaries in EU studies (Bickerton, Hodson and Puetter 2015c); it is when such borders are transgressed that this field is at its most vibrant and relevant for wider debates in politics and international relations.

Although the new intergovernmentalism emerged as a research agenda during the euro crisis it has been criticised for failing to account for the institutional dynamics set in motion by this crisis. This paper has challenged this view. The euro crisis, it has argued, illustrates well the problems of preference formation in the post-Maastricht period. The most pressing constraint on member state governments was not economic interest groups, which neither uniformly nor consistently supported preserving the eurozone in its current form, but the problems of legitimacy facing the EU and its member governments. Governments remained loyal to the euro in spite of the short-term temptations facing some member states to restore national currencies and sought to circumvent problems of legitimacy by avoiding the transfer of new competences to the Commission. Although the Commission saw its involvement in EU economic and fiscal surveillance deepen as a result of the euro crisis, it was the ECB and other de novo bodies that were the real institutional winners from the crisis, 
alongside the European Council and newly created Euro Summit. Moreover, heads of state or government reached agreement on these reforms and crisis resolution measures not simply through hard bargaining but via a process of consensus-seeking and deliberation that privileged cooperative solutions to the crisis and helped to bridge ideational differences that this period of turmoil for the single currency exposed. Although such efforts helped to save the single currency, they deepened the political disequilibrium facing the EU.

A question posed by this analysis is not whether the euro crisis is a painful case for new intergovernmentalism but whether it might actually be a convenient one. The high-stakes surrounding this crisis, the technocratic character of this policy domain and the scope for institutional innovation may, in other words, have been well suited to the intergovernmental working methods highlighted by this approach. On the face of it, other major crises to confront the EU reveal dynamics over the last decade speak to key claims of the new intergovernmentalism. Far from offering a 'deliberate, legitimate and functional response' to the European refugee crisis (Moravcsik 2018: 1669), member states such as Hungary pushed back against the Commission's refugee quotas for reasons that had less to do with commercial interests than contestation over European integration. Although the European Council eventually reached a consensus on how to handle the crisis, its European migration agenda inflamed those who criticised the EU for being too brutal in protecting Europe's borders as well as those who saw it as being too lax. As regards Brexit, David Cameron's failure to win popular support for the UK's continued membership of the EU in spite of strong support from key economic interest groups laid bare the problems of preference formation in the post-Maastricht period. His successor, Theresa May's, failure to strike a workable withdrawal agreement with the EU-27, moreover, offered a stark demonstration of what happens when a member state abruptly detaches itself from the European Council's deliberative and consensusseeking norms. 


\section{References}

Alexander, K. (2016). The European Central Bank and Banking Supervision: The Regulatory Limits of the Single Supervisory Mechanism. European Company and Financial Law Review, 24(13), 467-94.

Atkins, T. and Slater, S. (2015). Europe's bankers fear Brexit more than Grexit. Reuters Blog, 25 June.

Barroso, J.M. (2008). Preparation European Council: Speech to the European Parliament. SPEECH/08/509 Brussels 8th October.

Bauer, M.W. and Becker, S. (2014). The unexpected winner of the crisis: The European Commission's strengthened role in economic governance. Journal of European Integration, 36(3), 213-29.

Becker, S., Bauer, M.W., Connolly, S. and Kassim, H. (2016). The Commission: boxed in and constrained, but still an engine of integration. West European Politics, 39(5), 1011-31.

Bickerton, C.J., Hodson, D. and Puetter, U. (2015a). The new intergovernmentalism: European integration in the post-Maastricht era. Journal of Common Market Studies, 53(4), 703-22.

Bickerton, C.J., Hodson, D. and Puetter, U. (eds.) (2015b) The New Intergovernmentalism: States and Supranational Actors in the Post-Maastricht Era (Oxford: Oxford University Press).

Bickerton, C., Hodson, D. and Puetter, U. (2015c). Something new: A rejoinder to Frank Schimmelfennig on the new intergovernmentalism. JCMS: Journal of Common Market Studies, 53(4), 731-6.

Bohn, F. and De Jong, E. (2011). The 2010 euro crisis stand-off between France and Germany: leadership styles and political culture. International Economics and Economic Policy, 8(1), 7-14.

Bojovic, J., Munta, M. and Puetter, U. (2018). Problems in domestic preference formation - the case of the European Stability Mechanism. EMU Choices Working Paper Salzburg Centre of European Union Studies.

Borger, V. (2013). The ESM and the European Court's Predicament in Pringle. German Law Journal, 14(113-140.

Breen, M. (2012). The International Politics of Ireland's EU/IMF Bailout. Irish Studies in International Affairs, 23(1), 75-87. 
Bulmer, S. (2014). Germany and the Eurozone crisis: Between hegemony and domestic politics. West European Politics, 37(6), 1244-63.

Bulmer, S. (2015). Understanding the New Intergovernmentalism. In Bickerton, C.J. and Hodson, P., eds., The New Intergovernmentalism: States and Supranational Actors in the Post-Maastricht Era. Oxford: Oxford University Press.

Burley, A.-M. and Mattli, W. (1993). Europe before the Court: A Political Theory of Legal Integration. International Organization, 47), 41-.

Chassany, A.-S., Barker, A. and Robinson, D. (2015). Greece talks: 'Sorry, but there is no way you are leaving this room'. Financial Times, 13 July.

Cooley, A. and Spruyt, H. (2009). Contracting states: Sovereign transfers in international relations, Princeton, NJ: Princeton University Press.

Crespy, A. and Schmidt, V. (2014). The clash of Titans: France, Germany and the discursive double game of EMU reform. Journal of European Public Policy, 21(8), 1085-101.

Eichengreen, B. (2010). The breakup of the euro area. In Alesina, A. and Giavazzi, F., eds., Europe and the Euro. Chicago, IL: University of Chicago Press, pp. 11-51.

European Commission (2017a). White Paper on the Future of Europe. $\operatorname{COM}(2017) 2025$.

European Commission (2017b). Reflection Paper on the Deepening of Economic and Monetary Union. COM(2017) 291.

Commission (2008). EU G8 Members meeting in London on Financial Market Turmoil - advance statement from Commission President José Manuel Barroso. 29 January ISEC/08/02.

Fabbrini, S. and Puetter, U. (2016). Integration without supranationalisation: studying the lead roles of the European Council and the Council in post-Lisbon EU politics. Journal of European Integration, 38(5), 481-95.

Foster, C. and Frieden, J. (2017). Crisis of trust: Socio-economic determinants of Europeans' confidence in government. European Union Politics, 18(4), 511-35.

Gotev, G. (2017). Macron, Merkel: EU treaty change is not taboo. Euractiv, 23 June.

Granger, M.P. (2015). The Court of Justice's Dilemma-Between More Europe and Constitutional Mediation. In Bickerton, C.J., Hodson, D. and Puetter, U., eds., The New Intergovernmentalism: States and Supranational Actors in the PostMaastricht Era. Oxford: Oxford University Press, pp. 208-26. 
Grant Thornton (2013). The future of Europe Grant Thornton: International Business Report, London: Grant Thornton.

Grant Thornton (2015). The future of Europe Grant Thornton: International Business Report, London: Grant Thornton.

Gros, D. (2018). How to Exit the Euro in a Nutshell-'Il Piano Savona'. CEPS Commentary https://www. ceps. eu/publications/how-exit-euro-nutshell-il-piano-savona.

Haas, E. (1964). Technocracy, pluralism, and the new Europe. In Graubard, S. and eds., New Europe? Boston: Houghton Mifflin., pp. 149-66.

Haas, E.B. (1976). Turbulent fields and the theory of regional integration. International Organization, 30(2), 173-212.

Haas, E.B. (2004). The Uniting of Europe: Political, Social, and Economic Forces 19501957University of Notre Dame Press.

Hennessy, A. (2014). Redesigning financial supervision in the European Union (2009-2013). Journal of European Public Policy, 21(2), 151-68.

Hix, S. (2008). Why the EU needs (left-right) politics? Policy reform and accountability are impossible without it. Notre Europe Paris Research and European Issues, Policy Paper No. 19.

Hobolt, S.B. and Tilley, J. (2016). Fleeing the centre: the rise of challenger parties in the aftermath of the euro crisis. West European Politics, 39(5), 971-91.

Hodson, D. (2013). The little engine that wouldn't: supranational entrepreneurship and the Barroso Commission. Journal of European Integration, 35(3), 301-14.

Hodson, D. (2015a). The IMF as a de facto institution of the EU: A multiple supervisor approach. Review of International Political Economy, 22(3), 570-98.

Hodson, D. (2015b). De Novo Bodies and the New Intergovernmentalism: The Case of the European Central Bank. In Bickerton, C.J., Hodson, D. and Puetter, U., eds., The New Intergovernmentalism: States and Supranational Actors in the PostMaastricht Era. Oxford: Oxford University Press, pp. 263-87.

Hodson, D. (2018). The Macroeconomic Imbalance Procedure as European integration: a legalization perspective. Journal of European Public Policy, 25(11), 1610-28.

Hodson, D. and Maher, I. (2018). The transformation of EU treaty making: the rise of parliaments, referendums and courts since 1950, Cambridge: Cambridge University Press. 
Hodson, D. and Peterson, J. (2017). Theorizing EU Institutions: Why They Matter for Politics and International Relations. In Hodson, D. and Peterson, J., eds., The Institutions of the European Union, 4th Edition. Oxford: Oxford University Press.

Hodson, D. and Puetter, U. (2018). Studying Europe after the fall: four thoughts on post-EU studies. Journal of European Public Policy, 25(3), 465-74.

Hodson, D. and Puetter, U. (2019). The European Union in disequilibrium: new intergovernmentalism, postfunctionalism and integration theory in the postMaastricht period. Journal of European Public Policy (2019), Early View), 1-18.

Hoffmann, S. (1995). The European Sisyphus: Essays on Europe, 1964-1994Westview Pr.

Howarth, D. and Quaglia, L. (2014). The steep road to European banking union: constructing the single resolution mechanism. JCMS: Journal of Common Market Studies, 52(S1), 125-40.

Howarth, D. and Roos, M. (2017). Pushing the Boundaries. New Research on the Activism of EU Supranational Institutions. Journal of contemporary European research, 13(2), 1007-24.

Irish Times (2010). Merkel warns future of EU at stake. Irish Times, 13 May.

Jones, E. (2014). The Year the European Crisis Ended, Basingstoke: Palgrave Macmillan.

Juncker, J.-C. (2014). A New Start for Europe: My Agenda for Jobs, Growth, Fairness and Democratic Change, Brussels: European Commission.

Juncker, J.-C. (2017). State of the Union Address 2017, SPEECH-17-3165Brussels: European Commission.

Kalaitzake, M. (2017). The political power of finance: The Institute of International Finance in the Greek debt crisis. Politics $\mathcal{E}$ Society, 45(3), 389-413.

Karnitschnig, M. (2015). Euro countries quietly urge Grexit. Politico Europe, 17 July.

Kassim, H., Peterson, J., Bauer, M.W., Connolly, S., Dehousse, R., Hooghe, L. and Thompson, A. (2013). The European Commission of the Twenty-First Century, Oxford: Oxford University Press.

Kuhn, T. and Stoeckel, F. (2014). When European integration becomes costly: the euro crisis and public support for European economic governance. Journal of European Public Policy, 21(4), 624-41.

Le Pen, M. (2017). 144 engagements présidentiels. Paris, available at https://www.marine2017.fr/wp-content/uploads/2017/02/projet-presidentiel-marine-lepen.pdf (accessed on 9 October 2017). 
Lefkofridi, Z. and Schmitter, P.C. (2015). Transcending or descending? European integration in times of crisis. European Political Science Review, 7(1), 3-22.

Lequesne, C. (2016). The Eurozone crisis and European integration:'new intergovernmentalism' as a valid theory. In Saurugger, S. and Terpan, F., eds., In Crisis and Institutional Change in Regional Integration. Abingdon: Routledge, pp. 55-73.

Lindberg, L.N. and Scheingold, S.A. (1970). Europe's would-be policy.

Lundgren, M., Bailer, S., Dellmuth, L.M., Tallberg, J. and Târlea, S. (2019). Bargaining success in the reform of the Eurozone. European Union Politics), 1465116518811073.

Minenna, M. (2018). A look back: what Eurozone "risk sharing" actually meant. Financial Times Alphaville, 10 October.

Moravcsik, A. (1993). Preferences and power in the European Community: a liberal intergovernmentalist approach. Journal of Common Market Studies, 31(4), 473-524.

Moravcsik, A. (1998). The Choice for Europe: Social purpose and State Power from Messina to Maastricht, Ithaca, NY: Cornell University Press.

Moravcsik, A. (1999). A new statecraft? Supranational entrepreneurs and international cooperation. International Organization, 53(2), 267-306.

Moravcsik, A. (2012). Europe After the Crisis. Foreign Affairs, 91(3), 54-68.

Moravcsik, A. (2016). The great Brexit kabuki-a masterclass in political theatre. Financial Times, 8.

Moravcsik, A. (2018). Preferences, Power and Institutions in 21st-century Europe. JCMS: Journal of Common Market Studies, 56(7), 1648-74.

Morrilas, P. (2017). Juncker's State of the Union: Where now for multispeed Europe? LSE EUROPP Blog, 14 September.

Moulds, J. (2012). How Finland keeps its head above eurozone crisis. The Guardian, 24 July.

Niemann, A. and Ioannou, D. (2015). European economic integration in times of crisis: a case of neofunctionalism? Journal of European Public Policy, 22(2), 196-218.

Nugent, N. and Rhinard, M. (2016). Is the European Commission really in decline? JCMS: Journal of Common Market Studies, 54(5), 1199-215.

Papanikos, G.T. (2015). A Grexit would not be a catastrophe for all Greeks. LSE European Politics and Policy (EUROPP) Blog., 27 May. 
Peterson, J. (2015). The Commission and the New Intergovernmentalism: Calm within the Storm?' In Bickerton, C.J., Hodson, D. and Puetter, U., eds., The New Intergovernmentalism: States and Supranational Actors in the Post-Maastricht Era. Oxford: Oxford University Press, pp. 185-207.

Peterson, J. (2017). Juncker's political European Commission and an EU in crisis. Journal of Common Market Studies, 55(2), 349-67.

Pollack, M.A. (2003). The Engines of European Integration: Delegation, Agency, and Agenda Setting in the EU, Oxford: Oxford University Press.

Puetter, U. (2014). The European Council and the Council: New intergovernmentalism and institutional change, Oxford: Oxford University Press.

Puetter, U. (2016). The centrality of consensus and deliberation in contemporary EU politics and the new intergovernmentalism. Journal of European Integration, 38(5), 601-15.

Rosendahl, J. (2011). Finland agrees with Greece on loan collateral. Reuters, 16 August.

Roth, F., Jonung, L. and Nowak-Lehmann D, F. (2016). Crisis and public support for the Euro, 1990-2014. Journal of Common Market Studies, 54(4), 944-60.

Russack, S. (2017). How is Juncker's 'last-chance Commission' Faring at Mid-term? Swedish Institute for European Policy Studies (SIEPS), 2017: 4.

Sanjurjo Hanck, P.L. (2018). A Purposeful Opportunist? The Juncker Commission and EMU Reform. Bruges Political Research Paper no. 72.

Scharpf, F.W. (2011). Monetary union, fiscal crisis and the pre-emption of democracy. Zeitschrift für Staats-und Europawissenschaften (ZSE)/Journal for Comparative Government and European Policy, 2011(January), 163-98.

Schimmelfennig, F. (2014). European integration in the euro crisis: The limits of postfunctionalism. Journal of European Integration, 36(3), 321-37.

Schimmelfennig, F. (2015a). What's the News in 'New Intergovernmentalism'? A Critique of Bickerton, Hodson and Puetter. JCMS: Journal of Common Market Studies, 53(4), 723-30.

Schimmelfennig, F. (2015b). Liberal intergovernmentalism and the euro area crisis. Journal of European Public Policy, 22(2), 177-95.

Schmidt, V.A. (2018). Rethinking EU Governance: From 'Old' to 'New'Approaches to Who Steers Integration. JCMS: Journal of Common Market Studies, 56(7), 1544-61. 
Schmitter, P.C. (2005). Ernst B. Haas and the legacy of neofunctionalism. Journal of European Public Policy, 12(2), 255-72.

Schmitter, P.C. and Lefkofridi, Z. (2016). Neo-functionalism as a theory of disintegration. Chinese political science review, 1(1), 1-29.

Scipioni, M. (2018). De Novo Bodies and EU Integration: What is the Story behind EU Agencies' Expansion? JCMS: Journal of Common Market Studies, 56(4), 768-84.

Smith, H. (2015). Greece crisis: Yanis Varoufakis admits 'contingency plan' for euro exit. The Guardian, 27 July.

Usherwood, S. and Startin, N. (2013). Euroscepticism as a persistent phenomenon. Journal of Common Market Studies, 51(1), 1-16.

Van Esch, F.A. (2014). Exploring the Keynesian-Ordoliberal Divide. Flexibility and Convergence in French and German Leaders' Economic Ideas During the EuroCrisis. Journal of Contemporary European Studies, 22(3), 288-302. 


\section{Recent LEQS papers}

Codogno, Lorenzo \& van den Noord, Paul. 'The rationale for a safe asset and fiscal capacity for the Eurozone' LEQS Paper No. 144, May 2019

Simoni, Marco. 'Institutional Roots of Economic Decline: Lessons from Italy' LEQS Paper No. 143, April 2019

De Santis, Roberta. 'On Productivity Measurement and Interpretation: Some Insights on Italy in the European Context' LEQS Paper No. 142, March 2019

Avlijaš, Sonja. 'The dynamism of the new economy: Non-standard employment and access to social security in EU-28' LEQS Paper No. 141, February 2019

Besimi, Fatmir \& Monastiriotis, Vassilis. 'The Role of EU Integration in Accelerating Structural Reforms in the Western Balkans: Evidence, Theory and Policy' LEQS Paper No. 140, January 2019

Saka, Orkun \& Bircan, Çağatay. 'Lending Cycles and Real Outcomes: Costs of Political Misalignment' LEQS Paper No. 139, December 2018

Wolkenstein, Fabio. 'Transnational Partisanship and Networked Constituent Power in the EU' LEQS Paper No. 138, October 2018

Macchiarelli, Corrado 'What is the EU-UK relation all about? Tracking the path from monetary integration to "ever closeness"' LEQS Paper No. 137, September 2018

Meyer, Niclas 'EU break-up? Mapping plausible pathways into alternative futures' LEQS Paper No. 136, August 2018

Di Cataldo, Marco \& Monastiriotis, Vassilis 'An assessment of EU Cohesion Policy in the UK regions: direct effects and the dividend of targeting' LEQS Paper No. 135, June 2018

Innes, Abby 'First-best-world economic theory and the second-best-world of public sector outsourcing: the reinvention of the Soviet Kombinat by other means' LEQS Paper No. 134, May 2018

Bojar, Abel 'With a Little Help from My Friends: Ministerial Alignment and Public Spending Composition in Parliamentary Democracies' LEQS Paper No. 133, April 2018

Voss, Dustin "The Political Economy of European Populism: Labour Market Dualisation and Protest Voting in Germany and Spain" LEQS Paper No. 132, March 2018

Campos, Nauro F. \& Macchiarelli, Corrado "Symmetry and Convergence in Monetary Unions" LEQS Paper No. 131, March 2018

Costa Font, Joan \& Perdikis, Laurie 'Varieties of Health Care Devolution: "Systems or Federacies"?' LEQS Paper No. 130, February 2018

Calrsson, Ulrika "The Perennial Thirty Years' War" LEQS Paper No. 129, February 2018

Isiksel, Turkuler "Square peg, round hole: Why the EU can't fix identity politics" LEQS Paper No. 128, January 2018 


\section{LEQS}

European Institute London School of Economics Houghton Street WC2A 2AE London Email: euroinst.LEQS@Ise.ac.uk

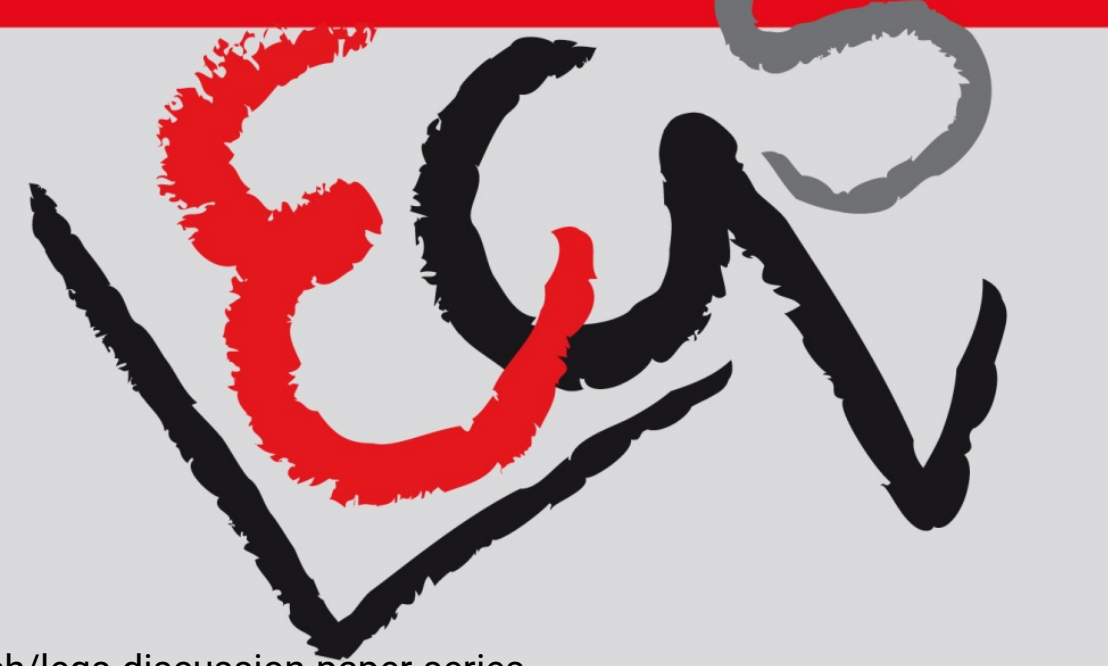

